\title{
Árdeli dallamok - A Kovács András Ferenc-olvasás lehetőségei a közoktatásban
}

\author{
Mészáros MÁrton \\ Károli Gáspár Református Egyetem, Bölcsészettudományi Kar
}

\begin{abstract}
KAF írásmüvészetének a közoktatás keretei közt történö tárgyalása számos izgalmas lehetöséget kinál az ezzel kísérletezö́k számára, noha kétségkivül jó néhány nehezen megkerülhetö problémát is fölvethet. A nehézségek minden bizonnyal a közoktatásban, illetve a tudományos igényü szakirodalomban használt terminológia - és fóként az alapvetö problémafókusz (irodalomfölfogás) - mindmáig nem kellő hatékonysággal áthidalt különbségében gyökereznek. Míg a KAF-szöveg rendkivül dialógusképesnek mutatkozik bizonyos teoretikus kérdezési irányokkal, a közoktatásban a mai napig elterjedt szerzóközpontú irodalomfelfogás nézőpontjából (a gyerekversek kivételével, ahol ezt a szempontrendszert hagyományosan nem érvényesitik) feltünően nehezen szólaltatható meg. Alapvetö probléma, hogy az ezredforduló költészeti tendenciáinak részletes tárgyalására a legtöbb esetben nem marad idö. Mindez azonban nem csupán akadály, hanem akár lehetöséget is kinálhat is a két „szféra” és a két irodalomfölfogás közti közvetitésre - és ezen közvetitö feladatra KAF költészeténél alkalmasabbat keresve sem találhatunk: tulajdonképpen KAF költészetét a közoktatásban tanitott szinte valamennyi fontos és hangsúlyos témakör, korszak vagy költöi életmü kapcsán „összehasonlitási alapként” vehetjük számításba: az effajta kortárs irodalmi jelenségekkel történö összehasonlitások pedig (akár konkrét szövegelemzések keretei közt, akár csupán példaként) legalább annyira segithetik az adott szerzo" vagy irodalomtörténeti korszak stilisztikai, poétikai, retorikai sajátosságaiban való elmélyülést, mint a kortárs magyar irodalom (vagyis az olvasókhoz, diákokhoz nyelvileg, kulturálisan legközelebb álló irodalmi alkotások) élóvé tételét. A tanulmány azokat a nagyobb problémacsoportokat veszi sorra, amelyek kapcsán KAF költészetének tanitása akár a közoktatás jelenlegi keretei közt is megvalósitható: a gyerekköltészet, a költői „maszkok”, alakmások valamint az intertextualitás problémakörét, majd egy függelékkel: néhány konkrét - a középiskolai oktatás menetébe is jól beilleszthetö - összehasonlitó elemzésre javasolt szöveg felsorolásával zárul. A felsorolásból látható, hogy szinte alig akad olyan, a középiskolában tanitott költoói életmü, amelynek vizsgálatához KAF költészete ne kinálhatna újabb szempontokat.
\end{abstract}

Kulcsszavak: gyerekköltészet, intertextualitás, szerepköltészet, kortárs magyar költészet, Kovács András Ferenc

Kovács András Ferenc (Szatmárnémeti, 1959) vagy ahogyan a szakirodalomban is emlegetik: KAF, az egyik legtöbbet elemzett, legnagyobb hatású kortárs magyar költő. Költészete a kilencvenes évek kritikai vitáinak egyik legfontosabb terepe volt (erről bővebben Korpa, Mészáros és Porczió, 2017). A KAF-értelmezés kulcsfogalmai - „identitásvesztés”, „kulturális emlékezet”, „nyelvi megelőzöttség”, ,intertextualitás”, „szerepköltészet” - a tradicionális szerzői pozíció elbizonytalanítására, majd felszámolására, végső soron pedig az irodalmi szöveg eredendő nyelvi, intertextuális létmódjára, irodalmiságára kérdeznek rá. Költészetének a mai magyar irodalomban szinte példa nélküli formagazdagságát a következetes részletességgel felépített költői maszkok, alakmások (Jack Cole, Lázáry René Sándor stb.) is segítik. KAF írásművészetének egyik meghatározó eleme a hagyomány általi megelőzöttség belátása, a költői megnyilatkozás „eredetiségéről” való lemondás. A forma iránti elkötelezettségben Csokonaival és Kosztolányival; sokszínűségében Weöressel rokonítható (vö. Harmath, 2013).

KAF írásművészetének a közoktatás keretei közt történő tárgyalása számos izgalmas lehetőséget kínál az ezzel kísérletezők számára, noha kétségkívül jó néhány nehezen megkerülhető problémát is fölvethet. A nehézségek minden bizonnyal a közoktatásban, és a tudományos igényű szakirodalomban használt terminológia - és főként az alapvető prob- 
lémafókusz (irodalomfölfogás) - mindmáig nem kellő hatékonysággal áthidalt különbségében gyökereznek. A fenti, hangsúlyozottan jelzésszerű felsorolásból is érzékelhetővé válik a KAF-értelmezői hagyományban meghatározó szerephez jutó fogalmi keret látványos inkompatibilitása a közoktatásban használt fogalomkészlettel és kérdésfölvetésekkel, amely probléma természetesen számos más, a szakmai reflexióban igen erősen kanonizált kortárs magyar irodalmi életmű (Esterházy Péter, Garaczi László, Parti Nagy Lajos stb.) taníthatóságát is ugyanilyen mértékben megnehezíti. Míg a KAF-szöveg rendkívül dialógusképesnek mutatkozik például a fent jelzett, teoretikus kérdezési irányokkal, a közoktatásban a mai napig elterjedt szerzőközpontú irodalomfelfogás nézőpontjából (a gyerekversek kivételével, ahol ez utóbbi szempontrendszert hagyományosan nem érvényesítik) feltűnően nehezen szólaltható meg. Alapvető probléma az is, hogy az ezredforduló költészeti tendenciáinak részletes tárgyalására a legtöbb esetben nem marad idő.

Mindez azonban nem csupán akadály, hanem akár lehetőséget is kínálhat is a két „szféra” és a két irodalomfölfogás közti közvetítésre - és ezen közvetítő feladatra KAF költészeténél alkalmasabbat keresve sem találhatunk. Sőt, a bevezetőben említett fogalmak értelmezésbe való bevonása („intertextualitás”, „hagyomány általi” vagy „nyelvi megelőzöttség”) tulajdonképpen szinte szükségszerüen oda vezet, hogy KAF költészetét a közoktatásban tanított szinte valamennyi fontos és hangsúlyos témakör, korszak vagy költői életmű kapcsán „összehasonlítási alapként” vehetjük számításba: az effajta kortárs irodalmi jelenségekkel történő összehasonlítások pedig (akár konkrét szövegelemzések keretei közt, akár csupán példaként) legalább annyira segíthetik az adott szerző vagy irodalomtörténeti korszak stilisztikai, poétikai, retorikai sajátosságaiban való elmélyülést, mint a kortárs magyar irodalom (vagyis az olvasókhoz, diákokhoz nyelvileg, kulturálisan legközelebb álló irodalmi alkotások) élővé tételét.

\section{Gyerekköltészet}

Óvodás kortól kisiskolás korig nyilvánvalóan KAF gyerekversei ajánlhatók - elsősorban mondókázásra, esetleg játékos verstanulásra. közös olvasásra. A szerző - aki pályája kezdetétől folyamatosan foglalkozik gyerekköltészettel - eddig öt gyerekvers-kötetet jelentetett meg. A Miénk a világ (Kovács, 2000) ${ }^{1}$ Vásárhelyi vásár (Kovács, 2003) és a Víg toportyán (Kovács, 2005) Erdélyben jelentek meg$^{2}$, ezért magyarországi terjesztésük kissé esetleges volt, szerencsére azonban ezen kötetek anyagának jó része megtalálható a Magvető által kiadott, és Takács Mari által igen invenciózusan és progresszíven illusztrált Hajnali csillag peremén (Kovács, 2007) ${ }^{3}$ című gyüjteményes anyagban is, amely nem csupán a három Erdélyben megjelent kötet anyagából válogat, de számos „felnőtteknek szánt” verset is - elsősorban a szövegek hangzó, játékos aspektusát kiemelve - gyerekversként kínál (újra)olvasásra. KAF gyerekköltészetére általában is jellemző ez a fajta „kettős kódolás": azaz, hogy miáltal a felnőtt és a gyerek olvasót (vagy hallgatót) - nyilvánvalóan a szöveg különböző regisztereiben -, egyaránt képes megszólítani. Szintén erre a kettős kódolásra, illetve kettős olvashatóságra épít a legutóbbi „gyerekvers-kötet”, az Egerek könyve (Kovács, 2015) is, amely Szalma Edit vicces, néhol kissé groteszk, a szövegekkel aktív dialógusba lépő illusztrációival jelent meg, a Magvető gondozásában.

Noha valamennyi kötet igen magas színvonalú, szép kiállítású kiadvány ${ }^{4}$, talán meg-

\footnotetext{
${ }^{1}$ Az illusztrációk képi világa a hetvenes évek gyerekkönyvillusztrációit idézi: mindez persze mit sem von le kétségbevonhatatlan művészi értékéből-

2 Utóbbi két kötetet a Deák Ferenc illusztrálta a mai, magyarországi olvasó számára kissé ódivatúan.

3 A kötet a Márai-programba is bekerült, így elvileg valamennyi magyar közkönyvtárban hozzáférhető.

4 Jelen sorok szerzőjének például az Egerek könyve különösen kedves darabja, annak ellenére is (vagy éppen azért), mert az önfeledt játékosság mellett elsősorban teoretikus problémákkal, a költőiség, irodalmiság olyan alapkérdéseivel szembesíti olvasóját, mint pl. a név, különösen a személynév körüli kétségek: a szövegek jelentős része már címében is jelzetten a tulajdonnévhez tartozó „személy”, „személyiség” szövegi megalkotását teszi
} 
Árdeli dallamok - A Kovács András Ferenc-olvasás lehetőségei a közoktatásban

kockáztatható az az értékelés, hogy a fenti kötetek közül komplexitás, az illusztrációk vitathatatlan gyerekközpontúsága, szépsége és játékossága, különösen pedig a tanításban való felhasználhatósága tekintetétében egyértelmüen a Hajnali csillag peremén emelkedik ki. A kötet egésze - az ismert gyerekverskötet-hagyományt követve - egyfelöl a naptári év eseményei alapján szerveződik (Vízkereszttől Karácsonyig), a verscímekben is következetesen jelezve mind a hónapok, mind az évszakok múlását (Vízkereszt, Farsangi bolondságok, Március, április, ó! Májusi nóta, Tavaszutó, Juharfában nő a nyár, Júniusi gombászás, Nyári varázslat, Július, Augusztusi sóhajtás, Öszelő, Gyorsan ellobbant a nyár, Szeptember, Ôszi nap, Szüreti mulatságok, Szüreti ének, Öszi hold, Télelő, December, Téli falucska, Erdélyi tél, Karácsonyi énekek, Betlehemes, Téli éjszakák). Ez a szerkesztési eljárás megkönnyíti a versek kontextualizálását a tanításban, lehetővé téve például, hogy minden hónapban vagy minden esemény? kapcsán közösen elolvassuk az arra az időszakra vonatkozó verset vagy verseket. Másfelől a napszakok (ébrenlét-alvás) logikáját is követi a kötet: hajnaltól (ehhez rendre a Hold képe társul) az éjszakáig (ehhez pedig a csillagoké) ívelő rendben közölve a verseket.

A Hajnali csillag peremén - ahogyan a KAFgyerekköltészet egésze - a gyereklíra „érzéki, játékos irányvonalát" (Lapis, 2017. 101. o.) követi, amely a gyermeki befogadáshoz igazodva erősen támaszkodik a nyelv hangzósságának, a költészet szekvencialitásának vagy ritmikusságának megtapasztalására, átélésére és örömére (ezért is mondogathatók, „mondókázhatók” ezek a versek); gyakran pedig - különösen a

feladatává; a névhez tartozó persona jellemvonásai pedig mintha legalább annyira magukból a nevekből következnének, mint megfordítva: (Cincius Mus Musculus - erős, Marczipáni Marcell - cukrász, Futokoda Cukijó - segítőkész stb.) Hasonlóképpen invenciózus és a teljes kötetet keretbe foglaló játék a gyereknyelv által egérhangként meghatározott "cin” szócska és általában a „ci” hangkapcsolat poétikai és akusztikai lehetőségeinek igen szórakoztató feltérképezése, amelyet a szöveg nem ritkán szintén a tulajdonnév problémájával együtt vizsgál (pl. Cincilla Prézli, XXX. Felicián, Alvinczy Nárcisz, Szőr Lőrinczy Jácint, Pucc Cini stb.). legkiemelkedőbb darabokban - az elbűvölő akusztikai élmény „varázslata” és a tartalom közti diskurzusra vagy éppen kontrasztra.

Erre a kontrasztra épül például a sokat elemzett Friss tinta, tinta, tinta című szöveg is, amely annak a Friss tinta (Banyó és mtsai., 2005) címü gyerekvers-antológiának is kötetcímadó darabja lett, amely a kétezres évek közepén szemléletformáló és úttörő szerepet vállalt a legfrissebb magyar gyerekköltészeti tendenciák fölmutatásban és népszerüsítésében.

\section{Kovács András Ferenc Friss tinta, tinta, tinta!}

Föloldja fent a holdat Az éji tentaoldat

Ma este még kicsordul Csillagfény sem csikordul Alusznak kósza macskák Malackák jó lovacskák Nem leng a régi hinta Terjeng az égi tinta Nincsen több ugra-bugra Álom száll kengurukra Nincsen víg ugri-bugri Alszik Balu Maugli Majom méhecske medve Durmol végleg feledve Hogy vadmézet nyalinta Nincs hinta meg palinta Most nem lehet lovazni Papírdarabkán pacni Föloldja fent a holdat Az éji tentaoldat Folt szunnyad így az irkán Nyugszik Bagira Sir Kán Bölcs nyúl ravaszdi róka $\mathrm{S}$ a rozzant óraműben Elpilledt kis manóka Álmában ring az inga Szivárgó ritka tinta Hegyek sorára csordul S a szó a szó a szó is Más oldalára fordul A nincs jelenbe olvad Föloldja fent a holdat Az éji tentaoldat Friss tinta tinta tinta 
Mészáros Márton

Aludj kincsem ma hol vagy

Krisztinka tinka tinka

Az andalító, trochaikus lejtésű sorokból építkező szöveg intenciója szerint egy altatódal, egy, csak a vers zárlatában lelepleződő (és valószínűleg csupán a felnőtt olvasó számára érzékelhető) csavarral, amely még a legkiválóbb értelmezők figyelmét is rendre elkerüli: a legtöbb, a szövegröl szóló elemzés ugyanis egyáltalán nem szembesül azzal az értelmezési lehetőséggel, hogy az „altató” esetleg olyasvalakihez szólhat, aki fizikai valójában nincs jelen, holott a vers zárlata, legalábbis szemantikai szinten, aligha értheto” másképpen: „Aludj kincsem ma hol vagy / Krisztinka tinka tinka." Ebből a kiindulópontból a nyugodni térő játékok, meselények, gyermeki elfoglaltságok (egyébként is kissé ellentmondásos, nyugtalanító képekkel teli) seregszemléje alapvetően teszi kétségessé a szöveg altatóként, vagyis a szó literális értelmében 'altatásra szánt beszédként' való olvashatóságát. A lista egyébként pozitív, vidám, gyermeki önfeledtséget sugalló elemeinek tagadásása (nem leng a régi hinta, nincsen víg ugri-bugri, nincs hinta meg palinta) tulajdonképpen tragikus veszteséglistává hangolja a szöveget; azt az értelmezést sem zárva ki, hogy a felsorolt tárgyak és cselekvések sora végső soron azon dolgok katalógusa, amelyek alkalmasak arra, hogy felébresszék az éppen a Friss tinta tinta című szöveget író „Én”-ben a távollévő Krisztinka emlékét, aki ennek az elszakítottságnak a traumatikus élményét a Friss tinta tinta címü szöveg formai rögzítésében igyekszik domesztikálni vagy megszelídíteni. A szó legpozitívabb értelmében vett pátosz (azaz az olvasóban keltett fájdalom, együttérzés, szánalom) abból a kettősségből fakad, hogy az olvasó csak a szöveg legvégén szembesül (ha szembesül egyáltalán) azzal, hogy tulajdonképpen egy el nem hangzó, esetleg csupán valamilyen emlékként felidéződött altatódal szövegét olvassa.

Hasonlóképpen erre a „kettős kódolásra”, forma és tartalom közti rejtett kontrasztra épül a kötet címadó verse, a Hajnali csillag peremén is:
Kovács András Ferenc

Hajnali csillag peremén

Hajnali csillag peremén

várjuk a reggelt, te meg én:

harmatozó fény a házunk, mélybe kalimpál a lábunk.

Vacsoracsillag peremén lessük az estét, te meg én: elsuhanó fény a házunk, reszket a mélyben a lábunk.

Földre bukó fény: te meg én. Éjbe hunyó fény: te meg én. Lobban a sóhaj-uszályunk: csönd ciripelget utánunk.

A szöveg - számos Weöres-gyerekvershez hasonlóan - a hangzás, az akusztikai élmény andalító muzsikája mögött az emberi létezés és nemlétezés szorongató egzisztenciális problémájának játékos, gyermeki, ugyanakkor mellbevágóan lényeglátó megfogalmazásaként is olvasható. A szöveg Én-je az Esthajnalcsillag „peremén” ül (tehát veszélyes, kiszolgáltatott, határhelyzetben) egy Te-vel. $\mathrm{Az}$ égitest szintén határhelyzetben van. A népi megfigyelések alapján, mint a neve is mutatja, először tünik fel az esti égbolton, hajnalban pedig a legtovább marad látható, és így mindig a „másik szférára” (a világosban a sötétre, a sötétben pedig a világosra) utal, és tulajdonképpen ez a kettősség lesz a szöveg fö szervező elve: fény-sötét, magasság-mélység, én-te, lét-nemlét. Az égitest az első két versszakban különbözőképpen van megnevezve (hajnali csillag vs. vacsoracsillag), amely megnevezésbeli különbség a „Mi” (te meg én) világhoz való különböző viszonyulásait, vagy általánosabban az emberi életút különböző állomásait mutatja. Míg az első strófa hangulatát és képeit a bizakodás, az örömteli várakozás határozza meg: „várjuk a reggelt”, „harmatozó fény a házunk”, sőt, még a lelógó lábak „kalimpálása” is gyermeki önfeledtséget sugall, a második strófában ugyanezek a képek gyorsulnak fel kontrollálhatatlanul, és válnak fenyegetővé: „elsuhanó fény 
Árdeli dallamok - A Kovács András Ferenc-olvasás lehetőségei a közoktatásban

a házunk”, „lessük az estét”, ahogy a lábak vidám „kalimpálása” is „reszketésbe” fordul át. A harmadik versszak tulajdonképpen ennek a szükségszerü bukástörténetnek a logikus végkifejlete, a fény és a hang hiányával végső soron az elmúlás élményét viszi színre: a „te meg én” itt már egyenesen azonosítódik az „éjbe bukó fénnyel”, a harmadik sor sóhaját pedig a "földre bukó fényként" is azonosítható „te meg én” eltűnése és az azt követő némaság, pontosabban (mivel a csönd - lévén éppen az akusztikai jel hiánya - akusztikai jelként nem érzékelhető) a csönd (borzongató, mert ember nélküli) „ciripelő” akusztikai élménye zárja le.

Vagyis, csak egyetérthetünk Lapis József találó összefoglalójával: „Kovács András Ferenc úgy írja meg ezeket a könyveket, hogy ki-ki megtalálhassa benne a maga számára vonzó elemeket, legyen az bár a ritmus és a hangsor mámora, a jelentésrétegek gyönyöre, a kulturális távlat deleje vagy a jelenlét közvetlen bizsergése (...) a szövegek eltérő módon hidalják át a befogadási stratégiák és szokások közötti távolságokat, s funkcionálnak kompként, közvetítőként olvasói világok között." (Lapis)

\section{Maszkok, alakmások}

Valószínűleg életkori sajátosságokból és a minket körülvevő technikai környezetből egyaránt következik, hogy a KAFköltészetnek egyik legkönnyebben tanítható és a középiskolásokat leginkább megragadni képes sajátossága az írói, költői alakmások vagy maszkok használata, amely a szerzőségre, a kulturális megelőzöttségre vonatkozó irodalomelméleti kérdések mellett olyan, a gimnazistákat eredendően is foglalkoztató problémák átgondolását segítheti, mint a „Ki vagyok én?” kérdése, az önidentikusság, vagy a digitális, illetve valós térben történő szerepjátszás, amely problémákról a mai diákok saját tapasztalattal is rendelkeznek (pl. fiktív facebook-profilok stb.). A magyar irodalomban a hetvenes évektől, nem utolsó sorban Weöres Sándor Psyché című munkája nyomán terjedtek el ezek az „alakmá- sok" (pl. Baka István - Sztyepan Pehotnij, Esterházy Péter - Csokonai Lili, Parti Nagy Lajos - Sárbogárdi Jolán stb.), amely elsősorban abban különbözik a hagyományos „álnevektől”, hogy ezekhez a „posztmodern” alakmásokhoz vagy maszkokhoz ${ }^{6}$ sajátos, a „valódi szerzőétől” gyakran radikálisan eltérő vers- és formanyelv, sajátos, beazonosítható téma- és motívumrendszer, önálló nézőpont, nem ritkán pedig, mint KAF „alakmásainak”, „personáinak” esetében is, részletesen kidolgozott kerettörténetek, fiktív életrajzok és bibliográfiák is tartoznak. ez a fikciós keret egyrészt a szövegekhez mellékelt jegyzetekből, másrészt pedig magukból a versekből fejthetö föl.

KAF számtalan alakmásából itt most csak néhányat van mód kiemelni: a legismertebb minden bizonnyal Lázáry René Sándor, aki a fikciós keret szerint 1859. szeptember 17-én született Kolozsvárott, latin és francia szakos tanár volt, de hivatalnokként dolgozott, Marosvásárhelyen vagy Marossárpatakon hunyt el 1927-ben. A történet szerint a (valóságban sosem létezett) költő kéziratait KAF találja meg egy marosvásárhelyi ház padlásán, és ő az, aki igyekszik az életművet gondozni, közreadni, „kikutatni” Lázáry életrajzát is.

Hasonlóan kidolgozott figura Jack Cole (Kovács, 2010b) is: a fiktív amerikai költő verseit KAF 'fordítja le' (ezek tehát fiktív fordítások). Ráadásul a Jack Cole (fiktív) szerzői név a fikción belül is csupán művésznév, Jack Cole „eredeti” (szintén fiktív) neve John Coleman volt, és egy (szintén fiktív) erdélyi származású, 48-as szabadságharcos - később az amerikai polgárháborúban őrnagyi rangig emelkedő - Kálmáncsehy József ükunokája ${ }^{7}$.

\footnotetext{
Mint ismert, Mikszáth Kálmán például nem kevesebb, mint 135 különböző néven jegyezte publikációit (vö. Németh, 2013).

6 Természetesen ez sem csupán a posztmodern irodalom jellemzője: akár az Arany János által megszólaltatott „Vojtina” is ide sorolható. (Vojtina Mátyás egyébként valóban létező „költő”, helyesebben a korban ismert kocsmai versfaragó - mai, kissé anakronisztikus, mégis meglepően pontos kifejezéssel - afféle 19. századi slammer volt.

7 Különösen szórakoztató, hogy a két fiktív életmű keresztezi egymást, ugyanis ugyanez a Kálmáncsehy
} 
Szintén önálló kötetben jelentek meg Alekszej Pavlovics Asztrov (fiktív) orosz költő versei és az életéről, költészetéről szóló (fiktív) életrajzi jegyzetek (Kovács, 2010a), amelyek nyilvánvalóAN az orosz irodalomban való elmélyülést segíthetik (a név „Alekszej” tagja talán Puskinra, a „Pavlovics” talán Csehov nevére utalhat).

És tulajdonképpen ugyanebbe a körbe sorolható egy valóban létező újgörög költő, a világhírű Konsztandínosz Kaváfisz verseinek „fordítása” is, a Hazatérés Hellászból: Kavafisz-átiratok című kötet, amelybe a valóban létező Kaváfisz-versek fordításai mellé néhány saját maga által írt „Kaváfisz-vers” (fiktív) fordítása is bekerült. A kötet nagy vitákat váltott ki, mert sok, a KAF-életmüben járatlanabb olvasó és kritikus nem vette észre (vagy nem akarta észre venni), hogy KAF a kötet végén maga is leplezte, melyek a saját és melyek Kaváfisz versei ${ }^{8}$.

Bármennyire szórakoztatóak is ezek a „maszkjátékok”, elsődleges funkciójuk KAF költészetében az, hogy gyakorlatilag végtelenné bővítsék a költő nyelv megszólalási lehetőségeit (vagyis a KAF-vers úgy is meg tud szólalni, mint egy VIII. századi kínai, és úgy is, mint egy XVIII. századi angol költő), azaz, képes ezen költészeti hagyományokkal termékeny párbeszédbe lépni. Mindez nagyban megkönnyíti KAF taníthatóságát - másfelől természetesen arra is alkalmas, hogy szem-

\footnotetext{
József, egyes Lázáry-versek tanúsága szerint Lázáry René Sándor nagybátyja volt, a két fiktív szerző: Lázáry és Jack Cole tehát rokonságban állnak egymással. Ha mindehhez hozzávesszük, hogy a (fiktív) Lázáry René Sándor (a fiktív) kerettörténet szerint „fordítója” a fiktív Fu An-kung VIII. századi kínai költőnek, a valóságban is létező Catulluskori latin rétornak, Caius Licinius Calvusnak (akinek a valóságban egyetlen verse sem maradt fenn, ha írt egyáltalán verseket), a szintén fiktív későrenszánsz-kori Marullo Pazzinak, valamint a XVIII. századi (fiktív) angol költőnek, Sir Andrew Blacksmithnek (magyarul: Kovács Andrásnak); akkor talán érzékelhetővé válik, milyen alaposan és játékosan felépített utalásháló alakul ki KAF költészetében.

${ }^{8}$ KAF saját „Kavafisz-verseit” a kerettörténet szerint az a „Két athéni füzet” tartalmazza, amely a „Blacksmithgyűjteményből” került elő: a Két Athéni Füzet akrosztikonja KAF, a Blacksmith-gyüjtemény pedig magyarul természetesen Kovács-gyüjteményt jelent.
}

besítse az olvasót a hagyományos „szerzőközpontú" irodalomfölfogás korlátaival...

\section{Intertextuális kapcsolódások}

Az intertextualitás kérdése, mely a KAFköltészetértelmezés meghatározó eleme, meglepően sok nehézséget, problémát okoz a tanításban, amit elsősorban a fogalommal kapcsolatos félreértések okoznak. Ez az általános problémakör is kitűnően megvilágítható KAF költészetén keresztül, a kérdések tisztázása után pedig - ahogyan utaltunk rá számos izgalmas és megvilágító erejü összehasonlító elemzés alapja lehet. (Itt jegyzendő meg, hogy a kortárs vagy posztmodern irodalom és költészet tárgyalása az intertextualitás ismeretének hiányában gyakorlatilag lehetetlen). Saját tanítási tapasztalataim azt mutatják, az intertextualitás fogalma (egy egyszerű elméleti bevezető után és sok példával), könynyedén és jól érthetően tanítható, az alábbiakban erre igyekszem példát kínálni.

Kovács András Ferenc ezt írja PRO DOMO című versében:

Csakén írok, versemnek höse: semmi. Vak ürnek voltál viselöse, Emmi vidám hasadban zsidó voltam s dán is, csordult a számon vád, vér, vodka, ánizs...

A strófa első sora láthatóan Babits A lírikus epilógja című versének híres első sorát idézi meg:

\section{Csak én bírok versemnek höse lenni elsö és utolsó mindenik dalomban: a mindenséget vágyom versbe venni, de még tovább magamnál nem jutottam}

Az intertextualitás jelenségét kissé felületes, de elterjedt nézet szerint a posztmodern egyik jellemző eljárásaként szokták leírni, mint afféle idézéstechnikát, amelynek során a szerzők mások műveiből kiragadott mondatokat, esetleg hosszabb szövegrészleteket használnak föl saját műveikben. Láthatjuk a fenti példából, hogy az intertextualitás nem szükségszerűen egyenes idézet, a két sorban 
Árdeli dallamok - A Kovács András Ferenc-olvasás lehetőségei a közoktatásban

csupán a „csak én” és a „versemnek” alak azonos, sok olvasóban mégis felidéződhet Babits verse. Söt, bár mindkét sor a versben megszólaló énről tesz kijelentést, éppen ellenkező dolgokat állítanak: $A$ lírikus epilógja azt mondja, hogy csak ez az Én tud a vers hőse lenni, míg KAF szövege azt, hogy ez a versben beszélő Én, aki a verset írja, nem csak nem "hőse a versnek”, de egyenesen a semmivel egyenlő (aki azonban rejtélyes módon mégis ír). Jobban megérthetjük az intertextualitás jelenségét, ha így fogalmazunk: az intertextualitás az a jelenség, amikor az olvasó a szövegben egy másik szöveg jelenlétét érzékeli. Fel kell hívnunk a figyelmet, hogy korántsem csupán megfogalmazásbeli, jóval inkább szemléletbeli különbség van a két definíció közt: míg az „idézéstechnika” azt sugallja, a szerző rakja bele az idézetet a szövegbe, amit aztán az olvasónak ki kell onnan olvasnia, a második definíció inkább azt, intertextualitásról csak akkor beszélhetünk, ha az olvasó saját műveltségének, korábbi olvasmányainak függvényében intertextusként ismerte föl az adott szövegrészt. Elképzelhető például olyan olvasó, aki nem ismeri fel A lírikus epilógjával való kapcsolatot, esetleg mert nem olvasta, nem emlékszik rá, vagy egyszerủen csak nem ugrik be neki, ez nem jelent szükségképpen hibás olvasást, csak azt, hogy a szöveg ezen regisztere számára nem fog megszólalni. Kovács András Ferenc szövegében például más, kevésbé nyilvánvaló intertextusokat is fölfedezhetünk: abból adódóan, hogy a szöveg hangja azt állítja magáról, hogy mielőtt megszületett volna, dán volt, akár a Hamletre is asszociálhatunk, de természetesen ez sem szükségszerü; az Én Hamlettel való azonosítása azonban természetesen új irányokba terelheti az olvasást. Mi haszna van ennek az eljárásnak? Az értelmezés szempontjából mindenekelőtt az, hogy összekapcsolja a két, illetve több szöveget, amelyek így egymás függvényében is olvashatók, és más szövegeket is bevonnak az értelmezés terébe. (Más megközelítések azt állítják, az intertextuális feszültséget akkor is érzékeli az olvasó, ha magát az intertextust nem ismeri föl, másképp fogalmazva, nem az intertextus azono- sítása, hanem idegenségének, idézettségének érzékelése a fontos.)

Mondhatjuk-e mindezek után, hogy az intertextualitás kifejezetten a posztmodernre jellemző jelenség? Semmiképpen sem, noha a posztmodern szövegek kétségkívül sok lehetőséget biztosítanak az intertextualitásközpontú értelmezések számára). Pápai Páriz Ferenc (1649-1716) például így határozza meg a paródia fogalmát: „Valamelly versnek követése, vagy azon, vagy más értelemmel" (Tarnai, 1990). Mint látható, Pápainál a fogalom nem a paródia mai ('irodalmi mű, stílus tréfás, torzító utánzata'), hanem általánosabb értelemben szerepel, mindazonáltal ez a fogalom talán nem is áll olyan távol attól, amit intertextualitásnak nevezhetünk. Sőt, ha figyelembe vesszük, hogy gyakran formai vagy tematikus hasonlóságok is létrehozhatnak intertextuális kapcsolatot, kijelenthetjük, hogy az intertextualitás az irodalmi szövegek olvasásának szükségszerű velejárója.

Az alábbiakban tehát, ha csak jelzésszerủen is, arra igyekszem példákat mutatni, hogy egyes középiskolai tananyagban szereplő szerzők szövegei kapcsán mely KAFszövegeket lehet, érdemes megvizsgálni, és ezekkel összefüggésben mely, a tudományos diskurzus és a középiskolai oktatás számára egyaránt izgalmas problémák vethetők föl. A javaslatokhoz rövid mintaelemzéseket is készítettem.

(Arany János: Vojtina ars poétikája, József Attila: Emberek, Favágó, Tiszta szívvel)

\section{Kovács András Ferenc J. A. szonettje}

Gallyát töröm csak, mert a töve vén: nem dönthető a korhadt líra fája vak föld alá nő visszás koronája, s a szó a szájban senki: jövevény.

\footnotetext{
9 Az elemzés nagyban támaszkodik H. Nagy Péter jóval részletesebb tanulmányára (H. Nagy, 2000). Az itt olvasható elemzés hosszabb változatát a Mai magyar irodalmi olvasókönyv című kötetemben közöltem először (vö. Mészáros, 2010).
} 
Megköt, felold a vándor szövevény hű mindenségben szétfutó gyökérzet göröngyeként ha pörgök, hörgök, érzek: a dallam nem változtat szövegén.

De van szöveg, mely falsít dallamán őszintébb volna ölni vagy rabolni... $\mathrm{S}$ a lélek dúdol: kába, gyatra holmi.

De mindezt mintha másról hallanám: nem a valót, csak annak én-imázsát, mint földöntúli lombok roppanását.

A J. A. szonettje igen világosan mutatja meg a magyar posztmodern költészet hagyományhoz való viszonyát. A cím egy J. A. monogramú szerzőtől eredezteti a verset, amelyet a monogram feloldásában érdekeltté tett olvasó valószínűleg a József Attila névvel helyettesít be. Ez a feloldás azonnal kétségekhez is vezet: tulajdonképpen ki is írja a verset, Kovács András Ferenc vagy József Attila? Melyik költői hang beszél a szövegben? Az első strófa intertextusa megerősíti ezt az azonosítást, a "gallyát töröm csak, mert a töve vén" sor ugyanis a legtöbb olvasóban József Attila Favágó című versét idézheti fel: „Ejh, döntsd a tőkét, ne siránkozz, / ne szisszenj minden kis szilánkhoz!" Míg a Favágó a tőke szó két lehetséges jelentése révén ('a fa töve' illetve 'gazdasági tőke, pénz') politikai tettre hívja föl olvasóját, sőt lehetségesnek is tartja a tőke kidöntését (a tőkésosztály megdöntését), KAF szövege csak "gallyak tördelésére” vállalkozik. A „korhadt líra fájának” kidöntése a költészeti hagyomány alapvető megújításának lehetőségét ígéri, ez azonban a szöveg logikája szerint két (egymással összefüggő) okból is illúzió. A "líra fája” legalább akkora gyökérzettel rendelkezik, mint a felszín fölött látható fa (vak föld alá nő visszás koronája); a lírát megújítani szándékozó költőnek csupán „jövevény” szavak állnak a rendelkezésére: éppen a költői tradíció által ráhagyományozott szavak, annak a tradíciónak a szavai, amelyet megújítani, „megdönteni” igyekszik.

A második strófában újabb József Attilaintertextusokra figyelhetünk föl, ezúttal az
Emberek című szonettből: „Kibomlik végül minden szövevény. / Csak öntudatlan falazunk a gaznak, / kik dölyffel hisszük magunkat igaznak / A dallam nem változtat szövegén." A J.A. szonettjében az Én a költészeti hagyomány, „a mindenségben szétfutó gyökérzet” foglya, nemhogy kibontaná ezt a „szövevényt” hanem éppenséggel feloldódik benne. A harmadik strófa is jól példázza ezt a feloldódást, hiszen az Én továbbra is József Attila-intertextusokban képes csak megnyilvánulni, a Tiszta szívvelt idézve meg: „Tiszta szivvel betörök, / ha kell, embert is ölök".

Az értelmezés elején föltett kérdés, „kinek a szövegét olvassuk?", egyre kevésbé válaszolható meg, a József Attila-intertextusok gyakorlatilag kiszálazhatatlanok KAF szövegéből. Az a költészeti hagyomány azonban, amelyben a KAF-szöveg Én-je feloldódik, nem szúkíthető kizárólag József Attila költészetére. A negyedik strófa még inkább megnehezíti a szövegben megszólaló hang azonosítását: „nem a valót, csak annak én-imázsát" sor ugyanis Arany János Vojtina ars poétikája című versének híres sorait értelmezi újra: „Nem a való hát: annak égi mássa / Lesz, amitől függ az ének varázsa." Míg Arany versében az „égi más” pozitívan értékelendő a valósághoz képest: valamiféle „valóság fölötti”, transzcendens tökéletesség biztosítja a költészet sikerét, KAF-nál az „énimázs” a „valóhoz” képest egyértelműen negatív: a költészetben megnyilvánuló hangnak csupán (például a költői tradícióból rámaradt) maszkok állnak a rendelkezésére, amely mögött valójában nincsen semmi. Innen olvasva pedig a J.A. monogram eddig biztosnak tűnő azonosítása is megkérdőjeleződhet, Arany János monogramja ugyanis A.J. (J.A. visszafelé olvasva), AMI végképp ellehetetlenítI a szöveg eredetének meghatározását.

\section{(Kosztolányi Dezső: Hajnali részegség)}

\section{Kovács András Ferenc: VERSFORGATÓ- KÖNYV. MUNKAFILM ${ }^{10}$}

\footnotetext{
10 Az elemzés részletesebb változatát az Alszik a fény című kötetben közöltem (vö. Mészáros, 2010).
} 
Árdeli dallamok - A Kovács András Ferenc-olvasás lehetőségei a közoktatásban

Kovács András Ferenc:

VERSFORGATÓKÖNYV. MUNKAFILM

Gulyás Gyulának szeretettel

Elmondanám talán

Így szinte kosztolányis.

Te közben észrevétlen,

Kigyúlt az égi műszer,

De más kéz forgat engem,

Mit ér a puszta létre

Hogy is kezdjem, barátom?

A Székely Vértanúknál,

Hol Fannistul, Julistul,

Élek, s hűlt éveim, mint

Föloldódnak kesernyés

Nyelek, s az életízről

Nem is tudom, de olykor,

Lefilmezel, meséltetsz

$S$ megint habozni késztetsz

Pedig fölösleges, mert

Vidékies valónkba,

Mintsem fölfogni képes

Hogy is mondjam? Szavam sincs,

Mint múlik kétezernégy,

Lehet, bevallhatom majd,

Fényévekben rokon,

Hogy voltom csak potom folt

Mely messzicsillanó

Elsiklik válaszom...

Minden szavam kitérő -

Ragyogni fárad arcom,

Uram, villants vakut!

Maradt időnk! Csapongunk

Bár senki sem lapoz ránk

Sosem tudhatni... Mégis

Ha rámfigyel, ha hallgat,

Mely megfakult, kiégett,

Nézd csak, feléd beszélek,

Akár lejárt, lejátszott,

Kazetta - nézd meg ismét

Ha mit ma látsz, az egyszer

És űrbe szállt mozikban

$S$ minden képsort a gépész

Hisz meghívott, miként én, neked. Ha még nem unnád.

Szavakban képanyag van.

ha itt vagy, tedd a munkád:

vesz már a gép az agyban...

s hiába kérdezed

vont nyelvi vértezet?

Te ismered lakásom

s tudod, hogy szent a helyszín,

könyvekkel egy rakáson

kávéban zsenge tejszín,

éjek setét levében

sincs egyre véleményem.

ha megjössz átutazván, magunkról, drága testvér, a lélek bárgyú hasznán több Párizs, Prága, Pest fér s több vérző, víg pofon, egy érző mikrofon...

ha épp megkérdezel:

s miképp telt kétezer?

tán tíz év múlva, bátyám,

míg elszívsz egy szivart,

a mennybolt zsúrkabátján,

konfettivel kivarrt...

Bocsásd meg enyhe bliccem, perc megszalad, fut óra,

s fejem kezemre biccen...

Pár pillanat-fotóra

kedélyes, halk dumában,

a képes albumában.

jobb volna néha félnem,

ha lát e néma filmen,

már-már szakadni véled.

ha védtelen beszélek, $\mathrm{s}$ forogni újra föltett

a mély azúrt s a földet!

a végtelenbe széled,

villogni kezd a portál,

örömmel visszapörget,

kinek nézője voltál. 
A témáját és formáját tekintve egyaránt meglehetősen különös Versforgatókönyv. Munkafilm (Kovács, 2006.59-60. o.) a vizualitás technicizáltságát tematizálva éppen a szöveg beszélőjével való „együttlátás” képességét, lehetőségét vonja meg olvasójától. Az elemzés során így lehetőségünk van reagálni korunk mediális változásaira, például arra, hogy a valóság számunkra gyakran nem közvetlen élményekben, hanem mediálisan, filmen, interneten közvetített, technikailag elöállított ezért manipulálható - képekben tárul föl. A Versforgatóköny. Munkafilm olyasfajta kettős címadás, amely az életmüben egyáltalán nem jellemző, ahogyan a cím mindkét tagja szokatlan szóösszetételek eredménye (ha a versforgatókönyv szóösszetétel nem egyenesen mediális oximoron, hiszen forgatókönyvet jellemzően nem versekhez, hanem filmekhez szokás készíteni). A cím alatti ajánlás pedig első olvasásra mintha inkább az új kötetetekben egyébként nem ritka alkalmi költemények sorába utalná a szöveget ${ }^{11}$. A szöveg - egyike a KAF-nál feltűnően kevés Kosztolányi-parafrázisnak ${ }^{12}$ - mind az általános beszédszituáció, mind a gyakorlatilag megkerülhetetlen intertextusok révén a Hajnali részegséget (Kosztolányi, 1975. 444-447. o.) idézi. Amenynyiben a Versforgatókönyvet a Hajnali részegség értelmezéseként fogjuk föl, nem csupán azt kell előzetesen kiemelnünk, hogy KAF szövege a Hajnali részegség (természetesen a Kosztolányi-recepció által is igen gyakran emlegetett) látványközpontúságára koncentrál, de azt is, hogy KAF verse az egyébként mindkét szövegen végrehajtható, a vizualitással is összefüggésbe hozható önreflexív olvasat lehetőségére is ráirányítja a figyelmet. Egy ilyen olvasat

11 Gulyás Gyula, az ajánlás címzettje dokumentumfilmrendező.

12 Noha a kötet címe, Álmatlan ég, nyilvánvalóan szintén a Hajnali részegségre utal. Ugyanitt jegyzendő meg, hogy ez a dolgozat Hajnali részegség értelmezésére különös tekintettel a vers recepciójának alig feldolgozható mennyiségére (talán elég itt csak a 2010 áprilisában Szabadkán megrendezett Hajnali részegség-konferencia mintegy negyven előadására utalnunk) - természetesen nem vállalkozhat, ahhoz legjobb esetben is csak némi hatástörténeti adalékkal járulhat hozzá. szerint a Hajnali részegségben az ablakon kitekintő alak számára feltáruló égbolt látványa, valamint a csillagok rá visszairányuló tekintete indítja el a „transzcendens” élményt, valamint az a vágya is a vizualitásban gyökerezik, hogy kommunikálja, verbalizálja azt: „de pattanó szivem feszitve húrnak / dalolni kezdtem ekkor az azúrnak". A dal, a húr megjelenésének okán az így elhangzó dal, akár általában a lírával, konkrétan a pedig a Hajnali részegség című szöveggel is azonosíthatóvá válik, a lenyűgöző látvány tehát a dalolás, versírás vágyát váltja ki az addig passzívan szemlélődő alakból. A Versforgatókönyv ezzel párhuzamos önreflexív olvasatában, a Hajnali részegség transzcendens élményével éles ellentétben, egy nagyon is profán aktust, egy filmforgatási szituációt mesél el. Az E/1-gyel jelölt alakhoz egy vendég érkezik, aki valamilyen okból filmre veszi a vendéglátóval folytatott beszélgetését (a harmadik strófa tanúsága szerint ráadásul rendszeresen). A Versforgatókönyv végső soron ennek a forgatásnak, és az ezt a forgatást elbeszélő versnek a forgatókönyve, ez a forgatókönyv jellegéből adódóan azonban nem leíró (a Hajnali részegséggel szemben nem az élmény lejegyzését szolgálja) hanem előíró, az E/1-gyel jelölt alak mintha uralni, irányítani akarná azt a filmet, amely róla készül, és amelyről a verset írja. Míg a Hajnali részegség célja a látvány kiváltotta élmény írásos rögzítése, a Versforgatókönyv a látvány előzetes szöveges irányítását kísérli meg. (Kosztolányi szövegében a dal írásos rögzítése a végső állapot ${ }^{13}$ míg KAF-nál, lévén szó forgatókönyvről, a szöveges rögzítés eleve csak egy olyan köztes fázisként jelenik meg, amelynek végcélja éppen nem nyelvi produktum, hanem egy film.)

Miközben a látvány rögzítésének több technikai médiuma is folyamatosan megjelenik a szövegben, nem hagyhatjuk figyelmen kívül, hogy a vers kiindulópontja egy szóbeli közlés („Elmondanám talán neked. Ha még nem unnád”), lényegében a nyelvet is a vizualitás közvetítésé-

\footnotetext{
13 Az, hogy az én az írásos lejegyzést választja, mintha a szóbeli közlés hallgatójának eleve feltételezett érdektelenségével is összefüggésben lenne.
} 
Árdeli dallamok - A Kovács András Ferenc-olvasás lehetőségei a közoktatásban

re alkalmas médiumként tételezve: („Szavakban képanyag van"). A két versben a szóbeli közlés címzettjének státusa különböző: míg a Hajnali részegség E/2-jel jelölt hallgatója passzív, mintha csak a beszédszituáció imitálása miatt lenne fontos, a Versforgatókönyv „Te"-je aktív, az ő kérdéseire válaszol a „hang”, az ő tevékenységéhez íródik a forgatókönyv, sőt, tulajdonképpen ő a látvány rögzítésének autentikusabb felelőse (ami a nyelv tulajdonképpeni közvetítőképességének elégtelenségével függ össze). Jól mutatja ezt a pozícióbeli különbséget az „Ám a gép az agyban zörgött tovább”, valamint a „Kigyúlt az égi müszer, vesz már a gép az agyban..." sorok összevetése: míg Kosztolányinál az agyban lévő gép az E/1-hez, KAF szövegében az E/2-höz kapcsolódik, a gép itt már egyértelműen a kamerára utal. Kosztolányi szövege a megszólítások révén végéig fönntartja az E/2 személyű beszédszituációt, a Versforgatókönyvnek csupán az első öt strófájában tűnik egyértelműen meghatározhatónak a beszéd címzettje, a hatodik versszak azonban elbizonytalanít: az E/1-gyel jelölt alak ugyanis az ötödik strófa végén elalszik (éles ellentétben a Hajnali részegség álmatlanságával), majd kilépve a forgatókönyvből az eddigi beszédpartnerrel közösen készített film E/3-mal jelölt nézőjének reakcióit próbálja meg elképzelni:

Sosem tudhatni... Mégis jobb volna néha félnem,/ Ha rámfigyel, ha hallgat, ha lát e néma filmen,/

Mely megfakult, kiégett, már-már szakadni véled.

Az utolsó strófa hangsúlyos aposztrofikus gesztusával ezután már ez a néző szólítódik meg E/2-ként: „Nézd csak, feléd beszélek, ha védtelen beszélek". A nézőt azonban éppen a Kosztolányi-szöveg fényében nem azonosíthatjuk a Kosztolányi szövegében megjelenő transzcendenssel, hiszen míg a Hajnali részegségben a beszélő/író alak az azúrhoz kezd el dalolni, KAF nézője kívülről tekint az azúrra is („nézd meg ismét a mély azúrt, s a földet!").

A szöveg zárlata legalább annyira enigmatikus, mint a cím: a 'forgatókönyvíró - operatőr - néző' hármas egy újabb elemmel bővül, a gépésszel, aki folyamatosan újrajátssza a filmet. A versforgatókönyv eredménye tehát a kazetta, amely az „Én” életével azonosítódik, és amely a szöveg értelmében erőteljesen rá van utalva valamiféle rögzítésre (aminek mediális státusa roppant ellentmondásos, hiszen egy olyan némafilm, amelyen folyamatosan beszélnek, és amit valaki hallgat). A leglényegesebb különbség tehát a Hajnali részegséghez képest éppen a tekintettel van kapcsolatban. Míg a Hajnali részegség Hangja a csillagok időtlen tekintetétől (autentikusként megélt) transzcendens élményhez jut, KAF-nál az operatőr- újrajátszható kazetta- gépész túltechnicizált és túlközvetített, ám feltétlenül igényelt rögzítettség, valamint az alig azonosítható megszólítottak okán nem képes ilyen élményhez jutni.

(Pilinszky János: Halak a hálóban, Őszi vázlat, Apokrif stb.)

Kovács András Ferenc: András evangéliuma ${ }^{14}$

1

Kezdetben volt a sírás: zord köveké a szélben, friss kerti fáké - a fény forró kardja ha zúgott.

2

Nyüzsögtek ott, vergődtek városok, mint hálóban halak: hiú világba vetettek miként magok.

3

Mert így szórattatunk szét.

4

Sosem leszünk bölcsebbek, jobbak, halhatatlanok: minden eltöröltetik.

5

Három vagy négy véletlen kézvonás: pusztában írt gazdátlan szép nevek - a többi névtelen homok.

\footnotetext{
14 Az elemzés részletesebb változatát az Alszik a fény címü kötetben közöltem (vö. Mészáros, 2010).
} 
6

Írás vagyunk s a kéz, mely

eltöröl - mintha a föld

fáradt hátát simogatná.

7

Mit írtam a porba, mit? S miért tüntettem el?

Tüzeknek üdvét, bűnjelét:

vak angyaloknak énekét?

A vers nem csak hangulatában, de hermetikus, tárgyias jellegében is emlékeztet Pilinszky költészetére, a cím mintha az Apokrifra utalna (lévén a Bibliában nem szereplő, tehát „apokrif” evangélium), egyes képei konkrétan is a Halak a hálóbant idézik meg, míg a nagyon egyértelmű bibliai utalások szintén távolabbról kapcsolódnak Pilinszky-vers világához. A szöveg egy KAF-nál meglehetősen gyakori, mégis nehezen azonosítható alakzattal kezdődik: „Kezdetben volt a sírás”. A sor nyilvánvalóan megkerülhetetlenül fölidézi János evangéliumának kezdő sorát: „Kezdetben volt az Ige”, és az Ige testé lett. A szöveg azonban a hasonló hangzás révén egy harmadik elemmel is kibővíti az alakzat hatókörét: a legtöbb olvasó számára a kezdetben volt az írás sort is bevonja az értelmezésbe. Ez az alakzat azért tehet szert kitüntetett jelentőségre, mert három olyan elemet (Ige - írás - sírás) képes egyetlen alakzatba sűríteni, amelyek (szemantikailag) a leghangsúlyosabban szembesítenek a költői nyelv medialitását érintő vitákkal, hiszen a „kezdetben" kifejezés, (a János evangéliuma értelmében is) a legvégső, illetve legelső eredetre vonatkozik (hogy tudniillik a kimondott, vagy a leírt szó élvez-e elsőbbséget).

A sírás szó használatával azonban első ránézésre megkerülhetőnek tűnik az elsőbbség kérdése, a szöveg ugyanis a sírás révén a nyelvnélküliségben határozza meg kezdőpontját. Az ötödik strófától kezdődően már szövegszerüen is az írás kerül a középpontba, a záróstrófa pedig mintha újra a kezdőstrófa mediális kétségei közé vezetné vissza az értelmezőt.

A hatodik versszak meghatározatlan többes szám első személlyel jelölt „hangja”, saját magát és a meghatározatlanságból adódóan végső soron akár a teljes teremtett világot is az írással azonosítja: „írás vagyunk”. Erről az egyébként rögtön ki is törlődő (írott) szövegről a hetedik strófában az derül ki, hogy valószínűsíthetően „vak angyaloknak énekét” rögzítette. (Az azonosítások láncolatában tehát a világmindenség egy olyan azonnal kitörlődő szövegként válik meghatározhatóvá, amely egy már korábban följegyzett, illetve esetleg megszólaltatásra váró éneket tartalmazott. KAF szövege sem a porba írt szöveg tartalmára vonatkozóan, sem pedig a kitörlés cselekvőjére, annak motivációira nézve nem szolgál biztos információval. Az angyalok porba írt énekének rejtélyessége, kétségessége így azt a szintén a János evangéliumában leírt történetet idézheti meg, amikor Jézus egy a farizeusokkal folytatott vitában, válasz helyet a porba ír. A történet annál is inkább rejtélyes, mert a Biblia szerint ez az egyetlen olyan alkalom, amikor Jézus nem beszél, hanem ír (sajátos módon azonban, a KAF-szöveghez hasonlóan, nem tudjuk meg, hogy mit.) A legelterjedtebb értelmezések szerint pontosan ugyanazt írja, amit utána mond: „Én sem ítéllek el téged, menj el és mostantól fogva többé ne vétkezz." Innen nézve nem zárható ki, hogy az eltüntetést pontosan a feljegyzés tökéletlensége teszi szükségszerűvé, hiszen a tökéletesség egyedül Isten sajátja; a szöveg eltörlésével viszont az angyalok éneke is hozzáférhetetlenné válik, és végső soron a kezdő, nyelvnélküli állapot áll újra elő, amely újra csak szóbeliség és írásbeliség egymásrautaltságát erősíti meg. Innen nézve a „kezdetben volt a sírás" sor legérdekesebb sajátossága éppen az, hogy miközben az sírás-írás alakzatában az akusztikai hasonlóság okán éppen a hangzás elsőbbségére irányítja a figyelmet, szemantikai szinten pontosan ennek ellenkezőjét, vagyis az írás elsőbbségét állítja.

\section{Függelék: összehasonlító elemzésre javasolt szövegek}

Zárásként, összegzés helyett csupán felsorolásszerűen és a teljesség igénye nélkül szeretnék javasolni néhány konkrét, a középiskolai oktatás menetébe is jól beilleszthető összehasonlítási, elemzési lehetőséget. A felsorolásból jól látható, 
Árdeli dallamok - A Kovács András Ferenc-olvasás lehetőségei a közoktatásban

hogy szinte alig akad olyan, a középiskolában tanított költői életmű (talán Szabó Lőrinc és Petőfi kivételével), amelynek vizsgálatához KAF költészete ne kínálhatna újabb szempontokat. A jelzett KAF-versek túlnyomó többsége elektronikusan is hozzáférhető a Digitális Irodalmi Akadémián (www.dia.hu), a Kovács András Ferenc digitalizált művei menüpont alatt.

Gilgames: Nászének, égetett agyag

Szophoklész: Antik tragédia

Horáciusz: Költözködés - Horátz után szabadon, Posztumusz Horácz 1999-böl

Catullus: Salve, o venusta Sirmio (Catullus az Irók Boltjában), Catullus a múzeumkert kutyáiról

Dante: Szélnek eresztett menazsériák, Sestina a költészet állapotáról

Villon: Ballade de la grosse Raison, Villoni sok feredések, Pótdal. Picinyke testamentum

Janus Pannonius: Gúnyirat Andreas Transylvanus ellen, Ungheretto-parafrázis

Balassi Bálint: Embléma ennen magáról, „Borivóknak való, Balassi-villanella, Valahány víg sírvers, Tört futamok citerára, Kiket Júliáról szerzett, Az Balassa nótájára

Cervantes: Marosvásárhelyi sorsok

Shakespeare: Az ötvenötödikre, Marosvásárhelyi sorsok, Epilógus a Fattyúdalokhoz, William Shakespeare közöttünk, Északi színház, Szinház az egész..., Lear király Cordeliához, Claudius király, Eléggé drámai jambusok, Ophelio Barbaro búcsúzik, A mintajambus egyre drámaibb, Will Shakespeare síremlékére, Shakespeare: Athéni Timon, W. SH eladja könyvtárát, Prospero-credo, Porospero-prológus, Shakespeare a Globe-tól búcsúzik, Shakespeare: Prospero elköszön stb.

Károli Gáspár: Öreg Biblia margójára

Szenczi Molnár Albert: Psalmus Transsylvanicus

Zrínyi Miklós: Invocatio ennen magához, Császári freskók, tévéhiradók, Summáya

Goethe: Bécsi lócit

Csokonai Vitéz Mihály: Csokonai-rögtönzés, némileg átigazitva, Háfiz sirhalma mellett, Köröcskézó maszkabál, „Ember és polgár leszek...”

Berzsenyi Dániel: Ezredévi ódákok, Ouverture. Tzimbalom-dall, Óarany óda, Berzsenyis, antik

Keats: Poéták egymás közt, Keats aligfinomkodik

Puskin: Románc, orosz románc

Kölcsey Ferenc: Kölcsey Ferenc lehajtja fejét
Vörösmarty Mihály: Lear király Cordeliához, Vörösmarty visszhangján, Rhapszódia három rajzolatban

Petőfi Sándor, Önarc kétezernégy nyarán

Arany János: A nyelszi bárdolatlanok, új walesi bárdok, Arany János azt üzente

Madách Imre: Arany János azt üzente

Charles Baudelaire: Sursum corda, Vaugirard. Adybandi Párisban, Prológ az olvasóhoz

Rimbaud: Rimbaud Etiópiában, Hös dalnokok histórikus karéneke az überallesbadeni Tapstéren

Verlaine: Lázáry úr Párisban

Tóth Árpád: Nyugatos fantáziák

Babits Mihály: Pro domo, Egy lírikus epilógja, Babits Mihályhoz, Messzebb... messzebb..., Szüreti ének, Babitsolás

Ady Endre: Új magyar Messiások, Kései Ady. Fragmentum, Ujj Nyugat, A lóvátett válaszol, Vaugirard. Adybandi Párisban, Vásárban voltunk adtak-vettek, Csucsai fénykép: Ady-zsoltár

Kosztolányi Dezső: A szegény kis színidirektor panaszai, Kosztolányi-stíl, Álmatlanság, Kosztolányi Vásárhelyen, Kosztolányi japánokat müfordit, Hommage à Kosztolányi, Hajnali tétlenség

Juhász Gyula: Szegedi költök

József Attila: J. A. kalapja, József Attila haja lángol!, J. A. disznaja, Szabadvendég, Bírálóimhoz. Születésnapomra. Plágium! Szárszói variációk, „Ember és polgár leszek..., Reminiszcencia, Néhány hamis medaillon,

T. S. Eliot: Ballade de la grosse Raison, Noctes Atticae

Radnóti Miklós: Radnóti-változatok

Illyés Gyula: Nem lesz elég

Pilinszky János: Pilinszky-portré. Lectio, Apokrif testamentum

Áprily Lajos: Pictura et sententia

Dsida Jenő: József Attila haja lángol!, Búcsú az angyalitól

Weöres Sándor: Weörescento, Weöres foreweör, Weöres a Mester, Lözsurnál dö Lüniver

Füst Milán: Kiélt artista füstölög magában

\section{Felhasznált irodalom}

Banyó Péter, Csányi Dóra, Edinger Katalin és Kovács Eszter (2005, szerk.): Friss tinta: Mai gyerekversek, Csimota - Pozsonyi Pagony, Budapest.

H. Nagy Péter (2000): A szöveghatárok feloldódása. In: Bednanics Gábor, Bengi László, Kulcsár Szabó Ernő és Szegedy-Maszák 
Mészáros Márton

Mihály (szerk.) Az irodalmi szöveg antropológiai horizontjai, Osiris Kiadó, Budapest.

Harmath Artemisz (2013): Szüntelen jóvátétel, Helikon, Budapest, 36-52.

Korpa Tamás, Mészáros Márton, Porczió Veronika (2017, szerk.): KAF-olvasókönyv, Fiatal Írók Szövetsége, Budapest.

Kosztolányi Dezső (1975), Hajnali részegség. In: Kosztolányi Dezső Összegyüjtött versei, Szépirodalmi, Budapest, 444-447.

Kovács András Ferenc (2000): Miénk a világ, Polis, Kolozsvár.

Kovács András Ferenc (2003): Vásárhelyi vásár, Koinónia, Kolozsvár.

Kovács András Ferenc (2005): Vig toportyán, Koinónia, Kolozsvár.

Kovács András Ferenc (2006): Versforgatókönyv. Munkafilm. In: Kovács András Ferenc Álmatlan ég, Éneklő Borz, Kolozsvárm 59-60.

Kovács András Ferenc (2007): Hajnali csillag peremén, Magvető, Budapest.

Kovács András Ferenc (2010a): Alekszej Pavlovics Asztrov hagyatéka, Bookart, Csíkszereda.
Kovács András Ferenc (2010b): Jack Cole daloskönyve, Magvető, Budapest.

Kovács András Ferenc (2015): Egerek könyve, Magvetö, Budapest.

Lapis József (2017): A kortárs magyar gyereklíra. In: Hansági Ágnes, Hermann Zoltán, Mészáros Márton és Szekeres Nikoletta (szerk.) Mesebeszéd. Fiatal Îrók Szövetsége, Budapest.

Lapis József (é.n.): Mauzológiai mélyfúrások. URL: http://www.szifonline.hu/?cikk_ID=426.

Mészáros Márton (2010): Az olvashatóság - hallhatóság - láthatóság határesetei Kovács András Ferenc költészetében. In: Bednanics Gábor (szerk.) „Alszik a fény”: Kosztolányi Dezső és Csáth Géza müvészete, FISZ-Ráció, Budapest.

Mészáros Márton (2010): Mai magyar irodalmi olvasókönyv, Hatágú Síp Alapítvány, Budapest.

Németh Zoltán (2013): Álnév és maszk. Líceum, Eger.

Tarnai Andor (1990): A paródia a XVI-XVIII. századi Magyarországon, Irodalomtudományi Közlemények, 94. 4. sz., 444-469.

\section{'Árdeli dallamok'. Possibilities of perception of KAF in education}

The works of KAF being included in the curriculum of public education provides a number of opportunities for those experimenting with it. It can however pose also some questions that would be hard to ignore. The difficulties most probably come from the fact that there is insufficient connection between the terminology (and especially the basic focus on problems) used in public education and in scientific literature. While the KAF text seems to be open for discussion with theoretical questioning, it is difficult to approach with the literature theory focusing on the author, which is used in public education. It is a common problem that there is no time to discuss contemporary poetical tendencies in detail. However, this is not necessarily and obstacle, but might provide an opportunity to create a connection between the two 'spheres' and the two approaches to literature - and for this, the poetry of KAF can be the best candidate. We can basically consider KAF's poetry can be a basis of comparison for all important topics, periods and oeuvres of other poets. Such comparisons with contemporary literary phenomena can help the understanding of the stylistic, poetic or rhetorical characteristics of a certain poet or literary period as much as bringing contemporary Hungarian poetry (meaning literary works that are linguistically and culturally closer to the readers and students) to life. This study evaluate those aspects that make the teaching of KAF's poetry possible to teach even in public education: the issue of nursery rhymes, poetical "masks" and images and intertextuality and with an appendix: some actual texts recommended for comparative analysis (which can be fit into the high school curriculum). .

Keywords: childrens poetry, intertextuality, mask, contemporary Hungarian poetry, Kovács András Ferenc

Mészáros Márton (2017): Árdeli dallamok - A Kovács András Ferenc-olvasás lehetőségei a közoktatásban. Gyermeknevelés, 5. 3. sz., 101-114. 